\title{
PALB2 mutations in German and Russian patients with bilateral breast cancer
}

\author{
Natalia Bogdanova $\cdot$ Anna P. Sokolenko $\cdot$ Aglaya G. Iyevleva • \\ Svetlana N. Abysheva $\cdot$ Magda Blaut $\cdot$ Michael Bremer $\cdot$ Hans Christiansen • \\ Margret Rave-Fränk · Thilo Dörk · Evgeny N. Imyanitov
}

Received: 16 November 2010/Accepted: 2 December 2010/Published online: 17 December 2010

(C) Springer Science+Business Media, LLC. 2010

\begin{abstract}
Since germline mutations in the PALB2 (Partner and Localizer of BRCA2) gene have been identified as breast cancer (BC) susceptibility alleles, the geographical spread and risks associated with PALB2 mutations are subject of intense investigation. Patients with bilateral breast cancer constitute a valuable group for genetic studies. We have thus scanned the whole coding region of $P A L B 2$ in a total of 203 German or Russian bilateral breast cancer patients using an approach based on high-resolution melting analysis and direct sequencing of genomic DNA samples. Truncating PALB2 mutations were identified in 4/203 (2\%) breast cancer patients with bilateral disease. The two nonsense mutations, p.E545X and p.Q921X, have
\end{abstract}

Natalia Bogdanova and Anna P. Sokolenko contributed equally to this work.

Electronic supplementary material The online version of this article (doi:10.1007/s10549-010-1290-4) contains supplementary material, which is available to authorized users.

N. Bogdanova $\cdot$ M. Blaut · T. Dörk

Gynecology Research Unit, Hannover Medical School,

Hannover, Germany

N. Bogdanova $\cdot$ M. Blaut $\cdot$ M. Bremer

Clinics of Radiation Oncology, Hannover Medical School,

Hannover, Germany

\author{
A. P. Sokolenko - A. G. Iyevleva · S. N. Abysheva . \\ E. N. Imyanitov $(\bowtie)$ \\ Laboratory of Molecular Oncology, N.N. Petrov Institute \\ of Oncology, St.-Petersburg 197758, Russia \\ e-mail: evgeny@imyanitov.spb.ru
}

A. P. Sokolenko - A. G. Iyevleva · E. N. Imyanitov Department of Medical Genetics, St.-Petersburg Medical Pediatric Academy, Alexsander Matrosov Street, 22, 194100 St.-Petersburg, Russia not been previously described whereas the two other mutations, p.R414X and c.509_510delGA, are recurrent. Our results indicate that $P A L B 2$ germline mutations account for a small, but not negligible, proportion of bilateral breast carcinomas in German and Russian populations.

Keywords $P A L B 2 \cdot$ Breast cancer $\cdot$ High-resolution melting $\cdot$ Mutation $\cdot$ Review

\section{Introduction}

Breast cancer $(\mathrm{BC})$ has an inherited component, and the high-penetrance breast cancer predisposing genes, BRCAI and $B R C A 2$, account for up to $10-30 \%$ of familial breast cancer clustering [1-3]. Other relevant genes, such as CHEK2, NBS1, PALB2, BRIP1, etc., also contribute to hereditary breast cancer, although their impact appears to

H. Christiansen · M. Rave-Fränk

Department of Radiation Therapy, University Medical Center

Göttingen, Göttingen, Germany

E. N. Imyanitov

Department of Oncology, St.-Petersburg Medical Academy

for Postgraduate Studies, Kirochnaya street, 41,

191015 St.-Petersburg, Russia 
be somewhat more population-specific [4]. The PALB2 (Partner and Localizer of BRCA2) gene is located on chromosome 16p12.2 and encodes for a protein involved in BRCA2-related pathways [5]. Its biallelic inactivation results in Fanconi anemia, while the presence of a germline mutation in the heterozygous state is associated with increased risk of breast, pancreatic, and possibly some other cancers (Table 1 and references therein). The geographical spread of PALB2 mutations has not been comprehensively analyzed yet, and several recent studies have failed to identify any $P A L B 2$ mutations in breast cancer series from their population [24-27]. The search for breast cancer predisposing mutations is considered to be particularly effective in patient series with a pronounced family history of the disease. However, the collection of multicase breast cancer families can be complicated in countries with low birth rate and/or recent historical turbulences and/ or lack of comprehensive registration of (familial) cancer cases. Others and we have suggested that patients with bilateral occurrence of breast cancer constitute a valuable group for genetic studies [28-31]. It has been calculated that the bilateral occurrence of breast cancer can be considered an equivalent of the presence of two affected firstdegree relatives [28].

We have previously employed population-specific series of patients with bilateral breast cancer to study the distribution of germline mutations in BRCA1, BRCA2, or CHEK2 [30, 32]. Here we report on the identification of $P A L B 2$ mutations in patients with bilateral breast cancer from Germany and Russia.

\section{Patients and methods}

The German case series consisted of 158 patients from Lower Saxony (Northern Germany) with bilateral breast cancer who had been recruited at the time they received radiotherapy either at Hannover Medical School during the years 1996-2005 $(n=112)$, or at the University Medical Center Göttingen during the years 2007-2009 $(n=46) .70$ (44\%) patients had synchronous bilateral BC (mean age: 59 years; age range $29-83$ years) and $88(56 \%)$ patients had metachronous disease (mean age for the first tumor: 51 years; age range 27-72 years; mean age for the second tumor: 60 years; age range 31-82 years). Five (3\%) women were diagnosed with her first primary below age 30 years, $16(10 \%)$ between 30 and 39 years, 30 (19\%) between 40 and 49 years, and $107(68 \%)$ at the age of 50 years or above. Family history revealed at least one first-degree relative with breast cancer in $29(18 \%)$ of the cases, and a second-degree family history of breast cancer in $14(9 \%)$ additional patients. Two women also had a personal history of ovarian cancer. Pathogenic BRCAl or
BRCA2 mutations were known in ten of the German patients $(6 \%)$; these patients were left within the study.

The Russian bilateral breast cancer patients were represented by 45 BRCA1/BRCA2 mutation-negative women, who underwent treatment in the N.N. Petrov Institute of Oncology (St.-Petersburg) in the years 1999-2009. 16 (36\%) patients had synchronous bilateral BC (mean age: 53 years; age range 30-77 years) and $29(64 \%)$ patients had the metachronous disease (mean age for the first tumor: 47 years; age range 25-77 years; mean age for the second tumor: 58 years; age range: $28-86$ years). Age at first BC onset was below 30 years in two $(4 \%)$ women, between 30 and 39 years in five (11\%) cases, between 40 and 49 years in $17(38 \%)$ patients, and 50 years or above in $21(47 \%)$ females. $13(29 \%)$ of the women reported a first-degree family history of the disease, and seven (16\%) additional patients had second-degree relatives affected by BC.

PCR amplifications were set up in the presence of the EvaGreen dye (BioBudget, Krefeld, Germany), and highresolution melting analysis was performed on the RotorGene 6000 real-time PCR machine (Corbett Research, Mortlake, Australia). Primer sequences are described in the Supplementary Table 1. Melting profiles were evaluated using the Melt Curve Analysis tool of the Rotor-Gene 6000 Series Software Version 1.7. All samples with suspicious melting behavior were then subjected to direct sequencing to identify the underlying substitution. The three common PALB2 polymorphisms, p.Q559R, p.E672Q, and p.G998E, were confirmed by allele-specific TaqMan assays on a 7500FAST Sequence Detection System platform.

The population frequency and the location of missense substitutions were assessed using the SNP database of the NCBI Genbank (http://www.ncbi.nlm.nih.gov/snp) and UniprotKB (http://www.uniprot.org/uniprot/). Bioinformatic analyses of missense substitutions were performed using SIFT (http://sift.jcvi.org/sift-bin/SIFT_BLink_submit.html) or PolyPhen-2 (http://genetics.bwh.harvard.edu/pph2/, with Q86YC2 as the protein identifier and in the HumDiv trained mode), which predict pathogenicity on the basis of evolutionary and structural calculations.

The project has been approved by the Ethical Boards of all participating research centers which contributed DNA samples to the study.

\section{Results and discussion}

All portions of the PALB2 coding region were successfully analyzed by high-resolution melting (Supplementary Fig. 1). Direct sequencing of samples with suspicious melting profiles revealed four truncating and several missense mutations. A list of the identified nucleotide sequence changes is provided in Table 2 . 
Table 1 Survey of inactivating $P A L B 2$ mutations in patients with cancer or Fanconi anemia

\begin{tabular}{|c|c|c|c|c|}
\hline Study & Country/ethnicity & Patients & PALB2 mutations & Founder effect \\
\hline \multicolumn{5}{|l|}{ Breast cancer } \\
\hline $\begin{array}{l}\text { Erkko et al. } \\
\text { [6] }\end{array}$ & Finland & $\begin{array}{l}113 \text { Familial, BRCA1/2 } \\
\text { negative }\end{array}$ & 1592delT (L531fs): 3 & $\begin{array}{l}\text { 19/947 (2\%) familial BC, } \\
8 / 1274(0.6 \%) \text { sporadic } \\
\text { BC, } 2 / 1079(0.2 \%) \\
\text { controls [7] }\end{array}$ \\
\hline $\begin{array}{l}\text { Rahman et al. } \\
\text { [8] }\end{array}$ & UK & $\begin{array}{l}923 \text { Familial, BRCA1/2 } \\
\text { negative }\end{array}$ & $\begin{array}{l}\text { 2386G }>\text { T (G796X): 1; 2982insT (A995fs): 1; } \\
\text { 3113G }>\text { A (W1038X): 2; 3116delA (N1039fs): 3; } \\
\text { 3549C }>\text { G (Y1183X): } 3\end{array}$ & \\
\hline $\begin{array}{l}\text { Tischkowitz } \\
\text { et al. [9] }\end{array}$ & $\begin{array}{l}\text { Canada } \\
\text { (Ashkenazi } \\
\text { Jews, French } \\
\text { Canadian, other) }\end{array}$ & $\begin{array}{l}68 \text { Familial, BRCA1/2 } \\
\text { negative }\end{array}$ & 229delT (C77fs) & \\
\hline $\begin{array}{l}\text { Foulkes et al. } \\
\quad[10]\end{array}$ & $\begin{array}{l}\text { Canada (French } \\
\text { Canadian) }\end{array}$ & $\begin{array}{l}50 \text { Young-onset } \\
(<50 \text { years }) \text { or familial }\end{array}$ & $2323 \mathrm{C}>\mathrm{T}(\mathrm{Q} 775 \mathrm{X})$ & $2 / 356(0.6 \%)$ young-onset $\mathrm{BC}$ \\
\hline Cao et al. [11] & China & $\begin{array}{l}360 \text { Young-onset } \\
(<35 \text { years }) \text { or familial }\end{array}$ & $\begin{array}{l}\text { 751C }>\text { T }(\mathrm{Q} 251 \mathrm{X}): 2 ; 1050 \_1051 \text { delAAinsTCT } \\
\text { (Q350fs): } 1\end{array}$ & \\
\hline $\begin{array}{l}\text { Garcia et al. } \\
{[12]}\end{array}$ & Spain & $\begin{array}{l}95 \text { Familial, BRCA1/2 } \\
\text { negative }\end{array}$ & 1056_1057delGA (K353fsX7) & \\
\hline $\begin{array}{l}\text { Sluiter et al. } \\
\text { [13] }\end{array}$ & $\begin{array}{l}\text { South Africa } \\
\text { (whites) }\end{array}$ & $\begin{array}{l}48 \text { Young-onset } \\
\text { (29-45 years) }\end{array}$ & 697delG (V233fs) & \\
\hline $\begin{array}{l}\text { Adank et al. } \\
\text { [14] }\end{array}$ & The Netherlands & $\begin{array}{l}110 \text { Cancer families with } \\
\text { BRCA2-like clinical } \\
\text { features, BRCA1/2 } \\
\text { negative }\end{array}$ & 509_510delGA (R170fs) & \\
\hline Balia et al. [15] & Italy & $\begin{array}{l}95 \text { Familial, BRCA1/2 } \\
\text { negative }\end{array}$ & 1317delG (G439fs) & \\
\hline $\begin{array}{l}\text { Ding YC et al. } \\
\text { [16] }\end{array}$ & USA & $\begin{array}{l}97 \text { Male, BRCA2 } \\
\text { negative }\end{array}$ & $3549 \mathrm{C}>\mathrm{A}(\mathrm{Y} 1183 \mathrm{X})$ & \\
\hline Papi et al. [17] & Italy & $\begin{array}{l}132 \text { Familial, BRCA1/2 } \\
\text { negative }\end{array}$ & $2257 \mathrm{C}>\mathrm{T}(\mathrm{R} 753 \mathrm{X})$ & \\
\hline Present study & Germany & 158 Bilateral & 509_510delGA (R170fs), 1633G > T (E545X) & \\
\hline Present study & Russia & $\begin{array}{l}45 \text { Bilateral, BRCA1/2 } \\
\text { negative }\end{array}$ & $1240 \mathrm{C}>\mathrm{T}(\mathrm{R} 414 \mathrm{X}), 2761 \mathrm{C}>\mathrm{T}(\mathrm{Q} 921 \mathrm{X})$ & \\
\hline \multicolumn{5}{|l|}{ Pancreatic cancer } \\
\hline Jones et al. [18] & USA & 97 Familial & $\begin{array}{l}\text { 172_175delTTGT (S58fs); IVS5-1G }>\text { T; 3116delA } \\
\text { (N1039fs); 3256C }>\text { T (R1086X) }\end{array}$ & \\
\hline $\begin{array}{l}\text { Tischkowitz } \\
\text { et al. [19] }\end{array}$ & Canada & $\begin{array}{l}254 \text { Familial and } \\
\text { sporadic }\end{array}$ & Deletion of the exons 12 and 13 & \\
\hline $\begin{array}{l}\text { Slater et al. } \\
\quad[20]\end{array}$ & Europe & 81 Familial & $\begin{array}{l}\text { 1240C }>\text { T (R414X), 508_509delAG (R170fs), } \\
\text { 3116delA (N1039fs) }\end{array}$ & \\
\hline \multicolumn{5}{|l|}{ Ovarian cancer } \\
\hline \multirow[t]{2}{*}{$\begin{array}{l}\text { Dansonka- } \\
\text { Mieszkowska } \\
\text { et al. [21] }\end{array}$} & Poland & 70 & 509_510delGA (R170fs) & $\begin{array}{l}2 / 339(0.6 \%) \text { ovarian cancer } \\
\text { cases, } 4 / 648(0.6 \%) \text { familial } \\
\text { BC, } 1 / 1310(0.08 \%) \text { controls }\end{array}$ \\
\hline & & Fanconi anemia & & \\
\hline Reid et al. [22] & Various & $\begin{array}{l}\text { 82, negative for } \\
\text { mutations in other } \\
\text { known FA genes }\end{array}$ & $\begin{array}{l}\text { Biallelic mutations: 395delT }(\mathrm{V} 132 \mathrm{fs}) / 3113+5 \mathrm{G}>\mathrm{C} \\
\text { (r.2835_3113del279/A946fs); 757_758delCT } \\
(\mathrm{L} 253 \mathrm{fs}) / 3294 \_3298 d e l G A C G A(\mathrm{~K} 1098 \mathrm{fs}) ; \\
\text { 2257C }>\mathrm{T}(\mathrm{R} 753 \mathrm{X}) / 3549 \mathrm{C}>\mathrm{A}(\mathrm{Y} 1183 \mathrm{X}) ; \\
\text { 2393_2394insCT (T799fs)/3350+4A }>\mathrm{G} \\
(\mathrm{r} .3350 i n s G C A G / F 118 f \mathrm{fs}) ; 2521 \mathrm{delA}(\mathrm{T} 841 \mathrm{fs}) / \\
\text { 3323delA (Y1108fs); 2962C }>\mathrm{T}(\mathrm{Q} 988 \mathrm{X}) / \\
\text { 3549C }>\mathrm{G}(\mathrm{Y} 1183 \mathrm{X}) ; 3116 \mathrm{delA}(\mathrm{N} 1039 \mathrm{fs}) / \\
\text { 3549C }>\mathrm{G}(\mathrm{Y} 1183 \mathrm{X})\end{array}$ & \\
\hline Xia et al. [23] & & Case report & Biallelic mutation: Y551X/deletion of the exons $2-6$ & \\
\hline
\end{tabular}


The analysis of 158 German bilateral breast cancer patients led to the identification of two (1.3\%) truncating mutations, both located in exon 4 of the PALB2 gene. The c. $1633 \mathrm{G}>\mathrm{T}$ allele (p.E545X) has not been described in prior literature, while the c.509_510delGA (p.R170fs) mutation appears to be recurrent in Poland, a neighboring country of both Germany and Russia [21]. The patient with the novel PALB2 mutation, p.E545X, was diagnosed at the age of 83 years as having bilateral invasive ductal carcinoma (IDC) with estrogen and progesterone receptor negative tumors (T2N1M0 and T2N0M0). She did not have an apparent family history of breast cancer, but reportedly her maternal grandmother suffered from stomach cancer and her sister died at the age of 67 from a cancer of unknown origin. The second German PALB2 mutation carrier, heterozygous for the c.509_510delGA frameshift mutation, was diagnosed with synchronous bilateral disease at the age of 63 years. She presented with bilateral invasive lobular breast cancer, with an additional invasive ductal component in one tumor; both cancers were of stage 1 (T1NOM0 and T1NOM0) and had positive estrogen and progesterone receptor status. Again, there was no family history of breast cancer, but her father suffered from a stomach cancer. None of the ten patients who carried a mutation in BRCA1 or BRCA2 was also a carrier of truncating PALB2 mutation; if we consider the frequency of $P A L B 2$ heterozygotes in BRCA1/2-negative German bilateral breast cancer cases, this estimate will approach to 2/148 (1.4\%).

The investigation of 45 (4.4\%) Russian patients with bilateral breast cancer revealed another two deleterious mutations. One woman carried the c.1240C $>$ T (p.R414X) allele in exon 4; this mutation has been previously described in a European family with pancreatic cancer [20]. This patient developed first disease at age 66 (IDC, T2N1M0, ER $+/ \mathrm{PR}+$ ) and the contralateral tumor at age 70 (Paget's carcinoma, T1N0M0, ER-/PR+). She reported that her mother was also affected by breast cancer. The second patient had a newly identified mutation, c.2761C $>$ T (p.Q921X). She was diagnosed with synchronous bilateral breast cancer at age 48 (both tumors: IDC, T4NOM0, ER+/PR-); her mother suffered from breast cancer, and her maternal grandfather was diagnosed with stomach cancer.

Six missense substitutions were identified besides the four truncating mutations (Table 2). The variants p.Q559R, p.E672Q, p.V932M, p.L939W and p.G998E are known to be relatively common both in breast cancer patients and in healthy controls [8]. Bioinformatic analysis using SIFT and PolyPhen-2 classified p.Q559R and p.V932M as benign, whereas p.E672Q, p.L939W and p.G998E were predicted as probably damaging by one or both of these software tools [8]. The new missense variant, p.K18R, was observed in two bilateral breast cancer cases from this study. It

Table $2 P A L B 2$ coding sequence alterations in 158 German and 45 Russian patients with bilateral breast cancer

\begin{tabular}{|c|c|c|c|c|c|}
\hline Exon & $\begin{array}{l}\text { Nucleotide } \\
\text { variation }\end{array}$ & Amino acid change & $\begin{array}{l}\text { Allelic counts in German } \\
\text { patients (relative fraction) }\end{array}$ & $\begin{array}{l}\text { Allelic counts in Russian } \\
\text { patients (relative fraction) }\end{array}$ & Reference \\
\hline 2 & $53 \mathrm{~A}>\mathrm{G}$ & K18R & $2(0.01)$ & - & This study \\
\hline \multirow[t]{7}{*}{4} & 509_510delGA & $\begin{array}{l}\text { Frameshift mutation } \\
\quad(\mathrm{R} 170 \mathrm{X})\end{array}$ & $1(<0.01)$ & - & $\begin{array}{l}\text { Dansonka- } \\
\text { Mieszkowska } \\
\text { et al. [21] }\end{array}$ \\
\hline & $807 \mathrm{~T}>\mathrm{C}$ & G269G & $1(<0.01)$ & - & This study \\
\hline & $1240 \mathrm{C}>\mathrm{T}$ & $\begin{array}{l}\text { Nonsense mutation } \\
\quad(\mathrm{R} 414 \mathrm{X})\end{array}$ & - & $1(0.01)$ & Slater et al. [20] \\
\hline & $1470 \mathrm{C}>\mathrm{T}$ & $\mathrm{P} 490 \mathrm{P}$ & - & $1(0.01)$ & rs45612837 \\
\hline & $1572 \mathrm{~A}>\mathrm{G}$ & S524S & $1(<0.01)$ & - & rs 45472400 \\
\hline & $1633 \mathrm{G}>\mathrm{T}$ & $\begin{array}{l}\text { Nonsense mutation } \\
(\text { E545X) }\end{array}$ & $1(<0.01)$ & - & This study \\
\hline & $1676 \mathrm{~A}>\mathrm{G}$ & Q559R & $18(0.06)$ & $6(0.06)$ & rs 152451 \\
\hline 5 & $2014 \mathrm{G}>\mathrm{C}$ & E672Q & $11(0.03)$ & $1(0.01)$ & rs 45532440 \\
\hline \multirow[t]{3}{*}{8} & $2761 \mathrm{C}>\mathrm{T}$ & $\begin{array}{l}\text { Nonsense mutation } \\
(\text { Q921X) }\end{array}$ & - & $1(0.01)$ & This study \\
\hline & $2794 \mathrm{G}>\mathrm{A}$ & V932 M & $2(0.01)$ & $3(0.03)$ & rs45624036 \\
\hline & $2816 \mathrm{~T}>\mathrm{G}$ & L939 W & $1(<0.01)$ & - & rs45478192 \\
\hline \multirow[t]{2}{*}{9} & $2993 \mathrm{G}>\mathrm{A}$ & G998E & $9(0.03)$ & $1(0.01)$ & rs45551636 \\
\hline & $3300 \mathrm{~T}>\mathrm{G}$ & $\mathrm{T} 1100 \mathrm{~T}$ & $7(0.02)$ & $1(0.01)$ & rs 45516100 \\
\hline 13 & $3495 \mathrm{G}>\mathrm{A}$ & S1165S & $1(<0.01)$ & - & rs45439097 \\
\hline
\end{tabular}


resides in a putative coiled-coil region of unknown functional importance and is predicted by PolyPhen- 2 to be probably damaging. Large-scale case-control comparisons as well as functional studies will be useful to identify any possible disease risks associated with these variants.

While the data indicate that $P A L B 2$ mutations are relatively uncommon in German and Russian populations, it may be noteworthy that the rate of mutation carriers appears somewhat higher in our series of bilateral breast cancer (2\%) than in most published series of familial breast cancer from other populations (Table 1). This would be in line with the assumption that patients with bilateral disease constitute a subgroup where the detection of rare at-risk alleles is particularly effective [28-31].

In summary, truncating $P A L B 2$ heterozygous mutations have been identified in 4/203 (2\%) breast cancer patients with bilateral disease. We conclude that PALB2 mutations contribute to a small fraction of bilateral breast cancer in Germany and Russia. The observation that two of the four mutations identified in our study are recurrent [20,21] may provide a rationale for mutation-specific screening efforts in extended series of Eastern and Central European cancer patients.

Acknowledgments We cordially thank Johann H. Karstens and Peter Hillemanns for their support of the studies on breast cancer genetics at Hannover Medical School. This study has been supported by the Russian Federation for Basic Research (grants 08-04-00369, 10-04-92110, 10-04-92601, 10-04-00962), the Federal Agency for Science and Innovations (contract 02.740.11.0780), the Commission of the European Communities (grant PITN-GA-2009-238132), and the Government of Moscow (grant 15/10). N.B. has been supported by the German Academic Exchange Program (DAAD), by the Friends of Hannover Medical School, and by a Hannelore-Munke stipend at Hannover Medical School. The initiation of our bilateral RussianGerman research collaboration has been supported by a grant from the German Research Foundation (DFG, Do 761/7-1).

Conflict of interest None.

\section{References}

1. Fackenthal JD, Olopade OI (2007) Breast cancer risk associated with BRCA1 and BRCA2 in diverse populations. Nat Rev Cancer 7:937-948

2. Turnbull C, Rahman N (2008) Genetic predisposition to breast cancer: past, present, and future. Annu Rev Genomics Hum Genet 9:321-345

3. Kurian AW (2010) BRCA1 and BRCA2 mutations across race and ethnicity:distribution and clinical implications. Curr Opin Obstet Gynecol 22:72-78

4. Walsh T, King MC (2007) Ten genes for inherited breast cancer. Cancer Cell 11:103-105

5. Tischkowitz M, Xia B (2010) PALB2/FANCN: Recombining cancer and Fanconi anemia. Cancer Res 70:7353-7359

6. Erkko H, Xia B, Nikkilä J, Schleutker J, Syrjäkoski K, Mannermaa A, Kallioniemi A, Pylkäs K, Karppinen SM, Rapakko K,
Miron A, Sheng Q, Li G, Mattila H, Bell DW, Haber DA, Grip M, Reiman M, Jukkola-Vuorinen A, Mustonen A, Kere J, Aaltonen LA, Kosma VM, Kataja V, Soini Y, Drapkin RI, Livingston DM, Winqvist R (2007) A recurrent mutation in PALB2 in Finnish cancer families. Nature 446:316-319

7. Heikkinen T, Kärkkäinen H, Aaltonen K, Milne RL, Heikkilä $P$, Aittomäki K, Blomqvist C, Nevanlinna H (2009) The breast cancer susceptibility mutation PALB2 1592delT is associated with an aggressive tumor phenotype. Clin Cancer Res 15: 3214-3222

8. Rahman N, Seal S, Thompson D, Kelly P, Renwick A, Elliott A, Reid S, Spanova K, Barfoot R, Chagtai T, Jayatilake H, McGuffog L, Hanks S, Evans DG, Eccles D, Breast Cancer Susceptibility Collaboration (UK), Easton DF, Stratton MR (2007) PALB2, which encodes a BRCA2-interacting protein, is a breast cancer susceptibility gene. Nat Genet 39:165-167

9. Tischkowitz M, Xia B, Sabbaghian N, Reis-Filho JS, Hamel N, Li G, van Beers EH, Li L, Khalil T, Quenneville LA, Omeroglu A, Poll A, Lepage P, Wong N, Nederlof PM, Ashworth A, Tonin PN, Narod SA, Livingston DM, Foulkes WD (2007) Analysis of PALB2/FANCN-associated breast cancer families. Proc Natl Acad Sci USA 104:6788-6793

10. Foulkes WD, Ghadirian P, Akbari MR, Hamel N, Giroux S, Sabbaghian N, Darnel A, Royer R, Poll A, Fafard E, Robidoux A, Martin G, Bismar TA, Tischkowitz M, Rousseau F, Narod SA (2007) Identification of a novel truncating PALB2 mutation and analysis of its contribution to early-onset breast cancer in FrenchCanadian women. Breast Cancer Res 9:R83

11. Cao AY, Huang J, Hu Z, Li WF, Ma ZL, Tang LL, Zhang B, Su FX, Zhou J, Di GH, Shen KW, Wu J, Lu JS, Luo JM, Yuan WT, Shen ZZ, Huang W, Shao ZM (2009) The prevalence of PALB2 germline mutations in BRCA1/BRCA2 negative Chinese women with early onset breast cancer or affected relatives. Breast Cancer Res Treat 114:457-462

12. García MJ, Fernández V, Osorio A, Barroso A, Fernández F, Urioste M, Benítez J (2009) Mutational analysis of FANCL, FANCM and the recently identified FANCI suggests that among the 13 known Fanconi Anemia genes, only FANCD1/BRCA2 plays a major role in high-risk breast cancer predisposition. Carcinogenesis 30:1898-1902

13. Sluiter M, Mew S, van Rensburg EJ (2009) PALB2 sequence variants in young South African breast cancer patients. Fam Cancer 8:347-353

14. Adank MA, van Mil SE, Gille JJP, Waisfisz Q, Meijers-Heijboer $\mathrm{H}$ (2010) PALB2 analysis in BRCA2-like families. Breast Cancer Res Treat. doi:10.1007/s10549-010-1001-1

15. Balia C, Sensi E, Lombardi G, Roncella M, Bevilacqua G, Caligo MA (2010) PALB2: a novel inactivating mutation in an Italian breast cancer family. Fam Cancer 9:531-536

16. Ding YC, Steele L, Kuan C-J, Greilac S, Neuhausen SL (2010) Mutations in BRCA2 and PALB2 in male breast cancer cases from the United States. Breast Cancer Res Treat. doi:10.1007/s10549010-1195-2

17. Papi L, Putignano AL, Congregati C, Piaceri I, Zanna I, Sera F, Morrone D, Genuardi M, Palli D (2010) A PALB2 germline mutation associated with hereditary breast cancer in Italy. Fam Cancer 9:181-185

18. Jones S, Hruban RH, Kamiyama M, Borges M, Zhang X, Parsons DW, Lin JC, Palmisano E, Brune K, Jaffee EM, Iacobuzio-Donahue CA, Maitra A, Parmigiani G, Kern SE, Velculescu VE, Kinzler KW, Vogelstein B, Eshleman JR, Goggins M, Klein AP (2009) Exomic sequencing identifies PALB2 as a pancreatic cancer susceptibility gene. Science 324:217

19. Tischkowitz MD, Sabbaghian N, Hamel N, Borgida A, Rosner C, Taherian N, Srivastava A, Holter S, Rothenmund H, Ghadirian P, Foulkes WD, Gallinger S (2009) Analysis of the gene coding for 
the BRCA2-interacting protein PALB2 in familial and sporadic pancreatic cancer. Gastroenterology 137:1183-1186

20. Slater EP, Langer P, Niemczyk E, Strauch K, Butler J, Habbe N, Neoptolemos J, Greenhalf W, Bartsch DK (2010) PALB2 mutations in European familial pancreatic cancer families. Clin Genet 78:490-494

21. Dansonka-Mieszkowska A, Kluska A, Moes J, Dabrowska M, Nowakowska D, Niwinska A, Derlatka P, Cendrowski K, Kupryjanczyk J (2010) A novel germline PALB2 deletion in Polish breast and ovarian cancer patients. BMC Med Genet 11:20

22. Reid S, Schindler D, Hanenberg H, Barker K, Hanks S, Kalb R, Neveling K, Kelly P, Seal S, Freund M, Wurm M, Batish SD, Lach FP, Yetgin S, Neitzel H, Ariffin H, Tischkowitz M, Mathew CG, Auerbach AD, Rahman N (2007) Biallelic mutations in PALB2 cause Fanconi anemia subtype FA-N and predispose to childhood cancer. Nat Genet 39:162-164

23. Xia B, Dorsman JC, Ameziane N, de Vries Y, Rooimans MA, Sheng Q, Pals G, Errami A, Gluckman E, Llera J, Wang W, Livingston DM, Joenje H, de Winter JP (2007) Fanconi anemia is associated with a defect in the BRCA2 partner PALB2. Nat Genet 39:159-161

24. Gunnarsson H, Arason A, Gillanders EM, Agnarsson BA, Johannesdottir G, Johannsson OT, Barkardottir RB (2008) Evidence against PALB2 involvement in Icelandic breast cancer susceptibility. J Negat Results Biomed 7:5

25. Guénard F, Pedneault CS, Ouellette G, Labrie Y, Simard J, Durocher F (2010) Evaluation of the contribution of the three breast cancer susceptibility genes CHEK2, STK11, and PALB2 in non-BRCA1/2 French Canadian families with high risk of breast cancer. Genet Test Mol Biomarkers 14:515-526
26. McInerney NM, Miller N, Rowan A, Colleran G, Barclay E, Curran C, Kerin MJ, Tomlinson IP, Sawyer E (2010) Evaluation of variants in the CHEK2, BRIP1 and PALB2 genes in an Irish breast cancer cohort. Breast Cancer Res Treat 121:203-210

27. de Sauty Chalon A, Teo Z, Park DJ, Odefrey FA, kConFab, Hopper JL, Southey MC (2010) Are PALB2 mutations associated with increased risk of male breast cancer? Breast Cancer Res Treat 121:253-255

28. Antoniou AC, Easton DF (2003) Polygenic inheritance of breast cancer: Implications for design of association studies. Genet Epidemiol 25:190-202

29. Imyanitov EN, Cornelisse CJ, Devilee P (2007) Searching for susceptibility alleles: emphasis on bilateral breast cancer. Int $\mathrm{J}$ Cancer 121:921-923

30. Fletcher O, Johnson N, Dos Santos Silva I, Kilpivaara O, Aittomäki K, Blomqvist C, Nevanlinna H, Wasielewski M, MeijersHeijerboer H, Broeks A, Schmidt MK, Van't Veer LJ, Bremer M, Dörk T, Chekmariova EV, Sokolenko AP, Imyanitov EN, Hamann U, Rashid MU, Brauch H, Justenhoven C, Ashworth A, Peto J (2009) Family history, genetic testing, and clinical risk prediction: pooled analysis of CHEK2 1100delC in 1, 828 bilateral breast cancers and 7,030 controls. Cancer Epidemiol Biomarkers Prev 18:230-234

31. Kuligina E, Reiner A, Imyanitov EN, Begg CB (2010) Evaluating cancer epidemiologic risk factors using multiple primary malignancies. Epidemiology 21:366-372

32. Steinmann D, Bremer M, Rades D, Skawran B, Siebrands C, Karstens JH, Dörk T (2001) Mutations of the BRCA1 and BRCA2 genes in patients with bilateral breast cancer. Br J Cancer 85(6):850-858 